\title{
Education and Behavioral Sciences Section
}

A Section of the Association of College and Research Libraries, American Library Association.

\section{BYLAWS}

\section{Article I. Name}

Sec, 1. The name of this organization shall be the Education and Behavioral Sciences Section of the Association of College and Research Libraries, a division of the American Library Association.

\section{Article II. Object}

Sec. 1. This Section shall represent librarians in the field of education and behavioral sciences. It will act for ACRL in cooperation with other professional groups in regard to those aspects of library service that require special knowledge of education and behavioral sciences.

Sec. 2. The Education and Behavioral Sciences Section has specific responsibilities:

(a) To advance the interests of education and behavioral science librarians.

(b) To promote library instruction in teacher education programs.

(c) To explore problem areas in curriculum materials administration and recommend actions for improvement.

(d) To review problems of the subject access systems for education and behavioral science literature and recommend effective ways of improving such systems.

(e) To explore possibilities for developing standards or guidelines for education library services for teacher education and educational research.

\section{Article III. Membership}

Sec. 1. Any member of the Association of College and Research Libraries may select membership in this Section by payment of dues to the American Library Association and any additional dues required for membership in ACRL and its sections. Every member has the right to vote. Any personal member is eligible to hold office.

\section{Article IV. Officers}

Sec. 1. Officers. The officers of this Section shall be a chairperson, a vice-chairperson/chairperson-elect, the immediate past chairperson, and a secretary.

Sec. 2. Terms. All officers and elected mem. bers of the Executive Committee shall serve until the adjournment of the annual meeting at which their successors are announced. In case of a va- cancy in any office, except chairperson, the replacement will be appointed by the chairperson.

(a) Chairperson. The chairperson shall serve for one year.

(b) Vice-chairperson. The chairperson-elect shall serve as vice-chairperson for one year. At its expiration, or earlier in case of a vacancy in the office of chairperson, the vice-chairperson succeeds to the office of chairperson.

(c) Secretary. The secretary shall serve for a term of two years.

\section{Article V. Meetings}

Sec. 1. The regular business meeting of the Section shall be held at the time and place of the Annual Conference of the American Library Association.

Sec. 2. Ten members shall constitute a quorum at a meeting.

\section{Article VI. Executive Committee}

Sec. 1. Composition. The Executive Committee shall consist of the officers, two members-atlarge appointed for one year by the chairperson, and the chairpersons of standing committees.

Sec. 2. Powers and Duties. The Executive Committee shall serve in an advisory capacity to the Program Committee, which consists of the chairperson and additional appointed members. The Executive Committee shall have the authority to conduct the business of the Section provided that none of its acts shall conflict with or modify any actions taken by ACRL and ALA.

Sec. 3. Meetings. Regular meetings of the Executive Committee shall be held at the time and place of the Annual Conference and Midwinter Meeting of the American Library Association. Special meetings may be called at the discretion of the chairperson.

Sec. 4. Quorum. A majority of the members constitute a quorum at any meeting of the Executive Committee.

\section{Article VII. Committees}

Sec. 1. Standing Committees. The EBSS chairperson may appoint and discontinue ad hoc and standing committees with the approval of the Executive Committee. All committees shall report to the Executive Committee and the membership through their chairpersons at the Executive Committee meetings and/or the annual membership meetings.

Sec. 2. Discussion Groups. Informal discussion groups, to meet at the time of an annual conference, may be formed by the chairperson or any five members. The EBSS chairperson may appoint a discussion group chairperson to serve 
until the discussion group elects its own chairperson.

\section{Article VIII. Nominations and Elections}

Sec. 1. Nominations. The vice-chairperson (chairperson-elect) of the Section, with the approval of the chairperson, shall appoint a Nominating Committee of at least three personal members of the Section. This committee shall present at least two candidates for each of the offices of the chairperson-elect, and, every second year, of secretary. Each candidate presented must have consented to the candidacy in writing and must be a member in good standing at the time of nomination. Representation of both education and the behavioral sciences should be considered in selecting nominees for office and other members of the Executive Committee.

Sec. 2. Elections. Elections shall be conducted by mail ballot in accordance with the procedures and deadlines established by the American Library Association. For each office, the candidate receiving the largest number of votes cast shall be elected. In case of a tie vote, the successful candidate shall be determined by lot. Candidates elected shall be reported at the annual meeting.

Article IX. General Provisions

Sec. 1. Wherever these Bylaws make no spe- cific provisions, the organization of and the procedure in this Section shall correspond to that set forth in the Bylaws of ACRL.

\section{Article X. Amendments}

Sec. 1. Proposals. Amendments to these Bylaws may be proposed in writing to the membership of the Section by the Executive Committee, or a committee appointed for this purpose, or by any five members. Proposals originating from the membership shall be fled with the secretary at least three months before the annual meeting.

Sec. 2. Voting. A copy of any proposed amendment shall be mailed by the secretary of the Section to each member at least thirty days before the annual meeting or shall be announced in College d- Research Libraries Neus in an issue prior to the annual meeting. A plurality vote of the members present and voting at an annual meeting or casting ballots in a mail vote shall carry a proposed amendment.

(Approved by the EBSS membership at ALA Annual Conference June 1978.) Bylaws Revision Committee: Laura Gowdy, Illinois State University; Lois J. Lehman, Indiana University; and Eva L. Kiewitt, chairperson, Indiana University.

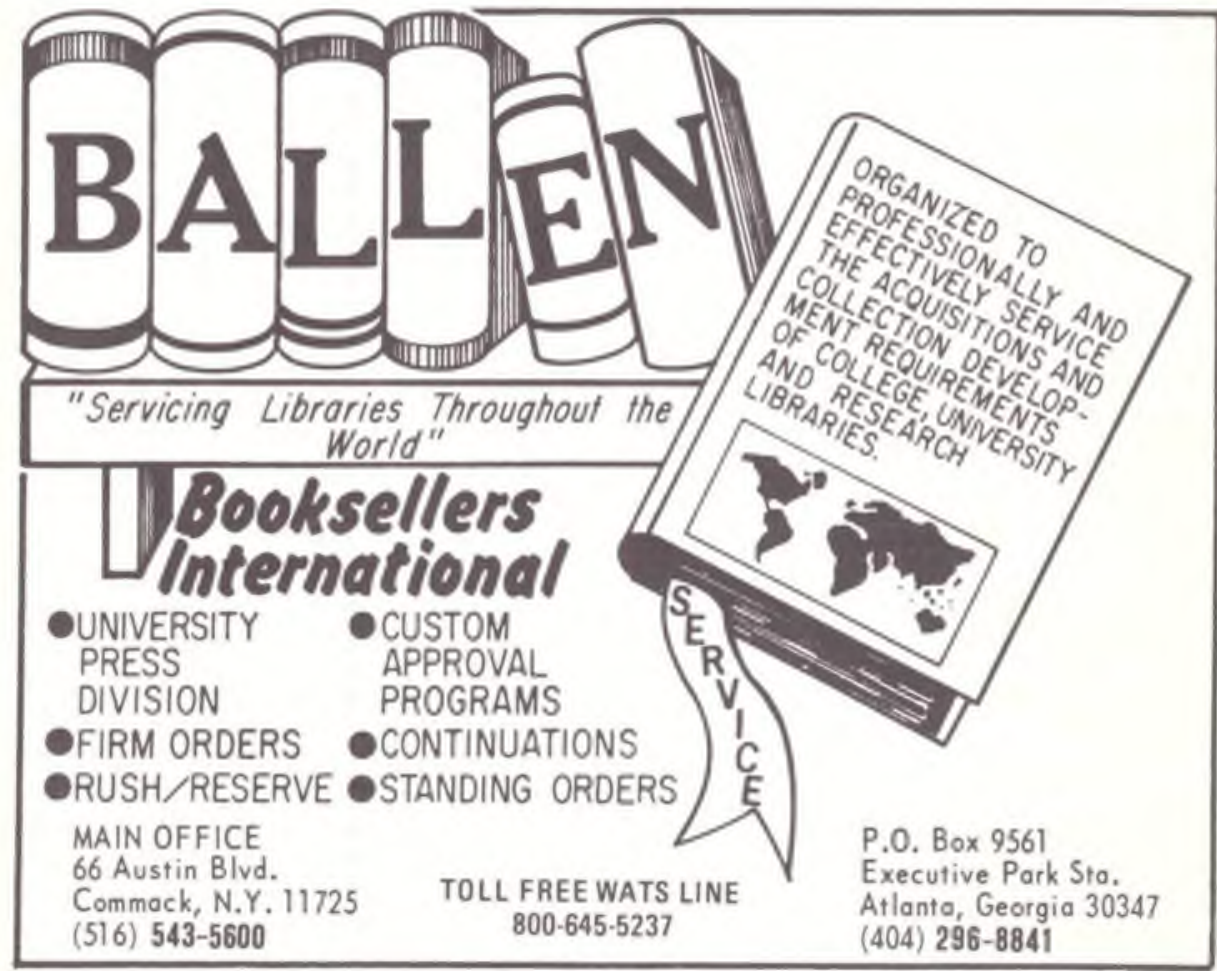

